\title{
Challenges faced in Implementing ICT in Higher Learning Institutions. A Botswana perspective
}

\author{
Kanos Matyokurehwa \\ Botho College, Gaborone, Botswana
}

\begin{abstract}
The Information and Communication Technology (ICT) is the driving force for the successful delivery of quality education in tertiary education level, but since its advent in the 90s it has not realized its full benefits to the developing countries especially Botswana in its tertiary education. The Government of Botswana is sponsoring students from primary level till to the tertiary level but much need to be done to make to have an educated nation that is technologically literate. This paper critically analyzes some of the challenges in implementing ICT in the Botswana's Tertiary Education System. The research has made use of data obtained from five major higher learning institutions in Botswana in the Gaborone city, from the study it was observed that the major challenges are to do with funding, student's late exposure to ICT technology and the curriculum design of institutions. This paper presents recommendations that can be adopted by the Tertiary Institutions in Botswana and some tertiary institutions in the region
\end{abstract}

\section{Introduction}

The word ICT can be summed up in the following definition as [1] "an umbrella term that includes any communication device or application, encompassing: radio, television, cellular phones, computer and network hardware and software, satellite systems and so on, as well as the various services and applications associated with them, such as videoconferencing and distance learning." The paper will be focusing on ICT as an effective tool to deliver or ameliorate learning in the tertiary institutions in Botswana with an ultimate aim to rally behind vision 2016 coined by the Government of Botswana to have an educated nation. The other side of the ICT coin is it propels or as this author made it simple [2] "ICT can be a catalyst by providing tools which teachers use to improve teaching and by giving learners access to electronic media that make concepts clearer and more accessible". So one can also agree with me that without a proper ICT in place the institution can find the going very tough and in most cases the institution will be fighting endless fights to extinguish the flame rather than preventing the fire from starting.
The research will present its findings and recommendations will be suggested to the Botswana Tertiary Institutions so that they can be adopted in future.

\section{Objectives}

- To consult management at the various tertiary institutions identified in the research and the staff on some of the challenges they are facing in implementing ICT at their institutions.

- To conduct literature review to some of the challenges faced by tertiary institutions in implementing ICT in higher education and how they were solved

- To analyze the curriculum design of tertiary institutions and how can that contribute to some of the problems in implementing ICT in higher education.

- To evaluate and disseminate the findings from the research so that the findings may be implemented in future

\section{Literature review}

In a research done [3] “... ICT application in Botswana was still at an elementary stage, mainly communications and recordkeeping and that the overall effect of ICT adoption on several organizational activities was moderately positive" but however the paper did not give more flesh on the challenges being faced in Botswana to fully adopt ICT. Another researcher [4] coined that ICT impact on the quality and quantity of delivering a teaching presentation in class. So the paper seeks to unearth some of the factors hindering the effective implementation of ICT in Botswana. In some countries like America and Uruguay in a bid to address the ICT challenges at grassroots, they adopted a program called [5] One Laptop per Child (OLPC) initiative where the learner the student and the instructor the teacher are given each a laptop to enhance their ICT skills which they have $24 / 7$ access to the laptop and also it is crucial to catch them while still young but in Africa and Botswana to be specific 
it can be a dream to be realized with donor aided funding.

In another initiative a country by the name Scotland they introduced a product called Glow [6] "It encourages collaboration and communication through its secure site, bringing schools, teachers or pupils from across the country together to share ideas. It is important for the promotion of best practice across all areas of the curriculum. "The approach means students and teachers can access the product and interact with it to share ideas across the country thus breaking geographical boundaries which is the main theme that ICT seeks to achieve. In Botswana there is an acute shortage of skilled manpower to come up with initiatives of this nature. With the advent of ICT the focus has drastically shifted from being centered on the teacher in the classroom delivering a lecture but rather to the student to be independent learners using ICT tools but how can the learning be ameliorated when the ICT resources are scarce and in some instances not available. According to the statistically speaking results published by the [7] World Bank's Knowledge Economy Index 2012 which shows the preparedness of the country to compete in the Knowledge Economy there is no African country in top 50 and Botswana is at number 85 out of 145 countries and this can be a good barometer on how far we need to travel to reach the mountain top.

\section{Current ICT in Botswana}

Currently the thrust is placed on students to learn the local language which is Setswana [8] "One central objective of primary education is for children to be literate first in Setswana and then in English". This framework means ICT is not given higher priority at grassroots level which will eventually affect the students when they enroll at tertiary education, since their ICT skills will be shaking. The Government of Botswana however is playing a critical role which can be further supported by this line of action [8] "creation of an enabling environment for the growth of an ICT industry in the country". The other development that is being done is to make sure all teachers are equipped at grassroots technologically [9] "All teachers to receive ICT training by December 31 , 2010". Still in the Education sector the Government through the Thuto Net [10] "is an expansive project that incorporates the Schools Connectivity Initiative, to link all secondary schools to the Internet. At the moment 104 secondary schools throughout the country have access to the Internet and the program is rolling out to other secondary schools." This is a clear indication that work is being done to address ICT awareness at grassroots at the moment. The other avenue that can be seen to be crippling the ICT in Botswana is funding as can be further supported by this [11] "A recommendation that $1: 7$ computer to student ratio be introduced into all schools by December 31, 2012 has been proposed, however the exact ratio has still to be determined". This indicates that the computer to student ratio is not adequate to fully implement ICT because one computer will be used by seven students.

On the infrastructure side [11] "There is also considerable disparity in terms of urban and rural access to ICT services. Challenges include the relatively high cost of PCs, the lack of electricity in many rural locations, and high charges for Internet usage". Many schools and colleges have computer laboratories in Botswana but the major challenge is the computer to student ratio which is still very high by international standards.

\section{Role of ICT in higher learning institutions}

One major advantage of ICT is to eliminate geographical boundaries, which means using internet as a resource a student will be able to access information or data located on remote places thereby enabling learning at anytime and at everywhere. This means that a student will be able to learn at their own pace and time in a $24 / 7$ manner, this goes a long way in aiding slow learners to grasp concepts they find challenging at their own time. This is a welcome move for institutions with limited books students can make use of the internet to access recent developments in their area of studies. Teleconferencing facilities also play a pivotal role in bridging the learning distance, which means the physical distance has been deleted when one is using the ICT tools.

The other dimension of ICT in higher learning institutions is to prepare the student for a job. Being technologically sound in this highly competitive global village is an added advantage to secure a job. This comes in a variety of forms like the ability to evaluate information using ICT tools and the ability to apply the knowledge acquired in classroom to come up with innovative products that would make life easier for other people like recent developments like Facebook and iPad to name but a few.

\section{Government's commitment to ICT}

For the successful delivery of ICT the commitment of the Government is of paramount importance, so this calls for a budget set aside each year for the ICT infrastructure. Countries like 
Sweden which are ranked number one on their readiness for ICT invested a lot of capital to make the dream a success. In a report published by the Government Offices of Sweden on the issue of infrastructure, the report pointed out that [12] "to enable digital services to be used and offered, there is a need for a basic infrastructure with electronic communications that work well. The Internet as a carrier of services has to be accessible and robust, and the information transmitted online has to be processed in a secure manner". To show the Government of Sweden's commitment to the ICT calls, [12] "In July 2011, the Government decided to appoint a commission of inquiry on measures to increase the use of ICT by small businesses".

The Government of Botswana is working flat out to improve the infrastructure of ICT. [ 13] "Botswana's ranking this year were helped by government's P70 million investment in the East Africa Submarine Cable System (EASSy) which is providing local data users with one of the world's fastest speeds at lower costs" this is a clear indication of the commitment by the Government to improve the overall infrastructure of the ICT also [13 ] "Another P250 million has been invested into the development of the West African Cable System (WACS), a submarine fibre optic cable that will this year bring even faster internet connectivity than the EASSy link"

\section{Methodology}

The research was done on five major tertiary institutions in Botswana and the participants were lecturers and the management. The research used a questionnaire to gather data from participants. A questionnaire was prepared with 17 questions divided into three categories. The first category comprised of six questions with a Yes/No respond, the second category consisted of eight questions based on a 5 Likert scales ranging from strongly disagree to strongly agree to capture the opinions of participants and the last category comprised of three open ended questions to capture the suggestions of the participants. There are eight major tertiary institutions in Botswana and the research represented $62.5 \%$ of the tertiary institutions. The research implemented a random sampling of participants and 20 questionnaires were distributed to each institution and 61 were completed and returned and this constituted a $61 \%$ of responses. The responses were coded into Statistical Package for Social Scientist (SPSS) to analyze the results.

The weakness with this research is the sample size which is not very large but in the near future another research could be conducted to cater for all tertiary Institutions in Botswana not the ones in Gaborone as was the case with the research.

\section{Results and discussions}

The results made use of variables that were used in the research so the results obtained are based on the views of the participants in the research conducted.

Table 1. Laptops given to students

\begin{tabular}{|c|c|c|c|c|c|}
\hline \multicolumn{6}{|c|}{ LaptopsToStudents } \\
\hline & & Frequency & Percent & Valid Percent & $\begin{array}{l}\text { Cumulative } \\
\text { Percent }\end{array}$ \\
\hline \multirow[t]{3}{*}{ Valid } & No & 53 & 86.9 & 86.9 & 86.9 \\
\hline & Yes & 8 & 13.1 & 13.1 & 100.0 \\
\hline & Total & 61 & 100.0 & 100.0 & \\
\hline
\end{tabular}

The table 1 shows the results obtained from participants on whether students are given laptops at the institution to study on their own pace and access the internet resources any time of the day but the results show that $86.9 \%$ said students are not given laptops. This means that they have to share the limited desktops available during school hours. This can be attributed to the cost associated with acquiring the laptops for students which can be far much beyond the reach of the institution, this is further shown that most institutions in Botswana do not provide laptops for their staff members which means the staff cannot do researches outside the school campuses so the cost is one of the major problem in implementing ICT.

\section{Table 2. Adequacy of student computer ratio}

\begin{tabular}{|ll|r|r|r|r|}
\hline \multicolumn{7}{|c|}{ ComputerRatio } \\
\hline & & Frequency & Percent & Valid Percent & $\begin{array}{c}\text { Cumulative } \\
\text { Percent }\end{array}$ \\
\hline Valid & No & 47 & 77.0 & 78.3 & 78.3 \\
& Yes & 13 & 21.3 & 21.7 & 100.0 \\
& Total & 60 & 98.4 & 100.0 & \\
Missing & System & 1 & 1.6 & & \\
Total & & 61 & 100.0 & & \\
\hline
\end{tabular}

The table 2 shows the responses from participants on the student computer ratio at their institutions if it is adequate. The results show that $78.3 \%$ said the ratio is not adequate which means the current computers at most institutions cannot support the number of students they enrolled so this can affect the proper implementation of ICT since the shift has moved to student centered learning.

This goes back to the above point that the cost associated with ICT is beyond the reach of many institutions because for the ICT tools to be available there is need for buildings, most tertiary institutions 
are private owned they do not have enough resources to construct more buildings to meet the students demand for those tools.

Table 3. ICT should be introduced in junior school

\begin{tabular}{|c|c|c|c|c|c|}
\hline \multicolumn{6}{|c|}{ ICTJuniorSchool } \\
\hline & & Frequency & Percent & Valid Percent & $\begin{array}{c}\text { Cumulative } \\
\text { Percent }\end{array}$ \\
\hline \multirow[t]{6}{*}{ Valid } & StronglyDisagree & 2 & 3.3 & 3.3 & 3.3 \\
\hline & Disagree & 2 & 3.3 & 3.3 & 6.6 \\
\hline & Nuetral & 2 & 3.3 & 3.3 & 9.8 \\
\hline & Agree & 13 & 21.3 & 21.3 & 31.1 \\
\hline & StronglyAgree & 42 & 68.9 & 68.9 & 100.0 \\
\hline & Total & 61 & 100.0 & 100.0 & \\
\hline
\end{tabular}

The table 3 shows the responses from participants on whether ICT should be introduced in junior school to enhance students to grasp the concepts of ICT at a tender age so that by the time they enroll at tertiary education they will be technologically sound. The table suggests that 68.9 strongly agreed that it is necessary to introduce ICT at junior schools since this will enable the students to learn the ICT at a tender age. ICT in Botswana is mostly offered by private schools in urban centers which are a bit expensive on the tuition for an ordinary parent to afford so there is need to reach the remote rural schools so that those students are not left behind. Most students in tertiary education in Botswana have problems when they enroll at tertiary education because they would be lacking the basic ICT skills.

Table 4. Does the institution design its curriculum?

\begin{tabular}{|ll|r|r|r|r|}
\hline \multicolumn{7}{|c|}{ CurriculmDesign } \\
\hline & & Frequency & Percent & Valid Percent & $\begin{array}{c}\text { Cumulative } \\
\text { Percent }\end{array}$ \\
\hline Valid & No & 34 & 55.7 & 57.6 & 57.6 \\
& Yes & 25 & 41.0 & 42.4 & 100.0 \\
& Total & 59 & 96.7 & 100.0 & \\
Missing & System & 2 & 3.3 & & \\
Total & & 61 & 100.0 & & \\
\hline
\end{tabular}

The table 4 looked at responses from participants on whether the institution design their own curriculum but $57.6 \%$ of participants said they don't so this in a way contributes to the challenge in implementing ICT because this shows the institution does not have the skilled manpower to do that and has a bearing on the successfully implementation of ICT. The institution will be relying on the expertise of other personnel mostly outside Botswana to design the curriculum for them and in most cases lacking relevance to the Botswana environment.
The other finding was of the language, Setswana which is Batswana's first language therefore English as a second language posses a big challenge for most students to express themselves fully on certain aspects. This notion is further supported by this line of thought [10] "language and academic success are closely related and that academic language proficiency is far more difficult to acquire in a second language". This clearly shows that it is difficult for someone who is not well versed in that language to be literate in technology since all the content is in English. Botswana is one country in Africa that is so proud of their mother language which poses a great threat in implementing ICT.

\section{Recommendations}

\subsection{Funding}

The two above issues about student computer ratio and giving students laptops can be solved through funding. The government may come up with an extra budget for ICT each year for tertiary institutions so that this can be solved. Another alternative is for the institutions themselves to sort other credit lines such as donors who can chip in with more resources.

\subsection{Curriculum design}

The design of curriculum should be done at the institution this will build confidence in the staff at the institution and will make the curriculum relevant to the Botswana environment and also bearing in mind the resources the institution will be having.

\subsection{Language}

This is rather a challenge to Botswana since English is their second language but mechanisms can be put in place like putting more emphasis on writing skills at junior schools so that by the time the students enroll at tertiary institutions they will be much better.

\subsection{Late exposure to ICT by students}

This can be solved by making ICT courses compulsory at junior schools so that they get to learn the ICT tools at an early stage and by the time they reach the tertiary level they will be technologically sound and this can only be done by the Government to incorporate this into their policy frameworks.

\section{Conclusion}

The research concluded that there are challenges that impact the proper implementation of ICT at 
Institutions of higher learning that falls under funding which can be seen by a big number on student computer ratio which needs to be addressed by the institutions of higher learning in Botswana. The government may also provide more funding towards ICT in the education sector. The other factor is of the language which contributes to some of the challenges in implementing ICT and a late exposure to ICT by students which makes it very hard for teachers to effectively deliver the content to students. This is an introductory research and a further study can be done to cater for all tertiary institutions in Botswana so that the research can be more representative.

The final word is that the problem here is not of the Government alone as was suggested by the Government of Sweden, the leading country in ICT readiness in a report published by the Government Offices of Sweden [12] "The Government's principal task is to create good conditions through rules, to formulate policy goals and to eliminate obstacles to development. However, if Sweden is to become the best in the world at exploiting the opportunities offered by digitization, everyone, beside the Government, has a role to play, individuals, businesses and organizations and municipalities, county councils and regional cooperation bodies"

\section{References}

[1]http://searchciomidmarket.techtarget.com/definition/IC T (16 March 2012)

[2] Unwin, T. (ed.). (2009). ICT4D. Information and communication technology for development. Cambridge: Cambridge University Press.

[3] Iyanda O (2008), 'Motivation, influences, and perceived effect of ICT adoption in Botswana organizations', International Journal of Emerging Markets, pp. $311-322$

http://www.emeraldinsight.com/journals.htm?issn=1746$8809 \&$ volume $=3 \&$ issue $=3 \&$ articleid $=1733109 \&$ show $=$ pdf ( 16 March 2012)

[4] Yusuf, M.O (2005) Information and Communication Technologies and Education: Analyzing the Nigerian National Policy for Information Technology. International Education Journal, 6(3), 316-321.

[5] http://laptop.org/en/laptop/hardware/index.shtml (16 March 2012)

[6]http://www.ltscotland.org.uk/Images/glowguideforparen ts_tcm4-672020.pdf ( 16 March 2012)

[7]http://siteresources.worldbank.org/INTUNIKAM/Resou rces/2012.pdf ( 22 October 2012)

[8] Shafika I, April 2009, http://ddpext.worldbank.org/EdStats/BWApro07.pdf (03 April 2012)
[9] http://www.balancingact-africa.com/news/en/issue-no243/new-botswana-ict-str/en (Access date: 03 April 2012)

[10] 2011 IST-Africa Consortium, http://www.istafrica.org/home/default.asp?page $=$ doc-by-id $\&$ docid $=5194$ (28 October 2012)

[11] Cummins, J. (1996) Negotiating Identities: Education and empowerment in a diverse society.

Ontario: California Association for Bilingual Education

[12]http://www.government.se/content/1/c6/18/19/14/70f4 89cb.pdf (28 October 2012)

[13]http://www.mmegi.bw/index.php?sid=4\&aid=212\&di r=2012/April/Friday13 (28 October 2012) 